\section{Measurement of Alkaline Earth Ion Con- centrations by Rennet Action}

THE relatively high temperature coefficient of the second or cationic precipitation stage of rennet action on casein allows its separation from the first or enzymic stage to be made by appropriate choice of temperatures ${ }^{1}$. Thus the first stage can be completed at $0-5^{\circ} \mathrm{C}$., and the second afterwards initiated at about $35^{\circ} \mathrm{C}$. The coagulation time at the higher temperature, extremely sensitive to variations in alkaline earth ion concentration within a fairly narrow range, can then serve as a measure of such concentrations.

Measurements are made on solutions of the appro. priate caseinate, relatively small volumes of which have been brought, by dialysis at $0-5^{\circ} \mathrm{C}$., into equilibrium with the solutions to be tested and a suitable range of standards. Solutions tested and standards for comparison should both agree approximately in content of ions of other valencies, the presence of which, particularly of polyvalent anions, influences the alkaline earth ion concentration for coagulation.

Determinations made by this method of the dissociation constants of calcium and barium citrates, $K=\left[\mathrm{Me}^{++}\right] \times\left[\mathrm{Citr}^{\prime \prime}{ }^{\prime \prime}\right] /\left[\mathrm{Me} \mathrm{Citr} .^{\prime}\right]$, at $2^{\circ} \mathrm{C}$. and an ionic strength $\mu 0.03$ give the values $0.35 \times 10^{-3}$ and $1.2 \times 10^{-3}$ respectively, in fair agreement with those obtained by other methods ${ }^{2,3}$.

A fuller account of this work with further applica. tions will appear elsewhere.

Dairy Chemistry Department,

G. T. PYNE

University College,

Cork. June 28.

1 Berridge, N. J., Nature, 149, 195 (1942).

'Hastings, A. B., McLean, F. C., Eichelberger, L., Hall, J. L., and Da Costa, E., J. Biol. Chem., 107, 351 (1934).

${ }^{3}$ Jaseph, N. R., J. Biol. Chem., 164, 529 (1946)

\section{Purity of Diphenylene Oxide (Dibenzofuran)}

WE wish to direct attention to the anomalous melting points $\left(82-87^{\circ} \mathrm{C}\right.$.) quoted in the literature ${ }^{1-7}$ for diphenylene oxide. It is likely that these anomalies are due in part to the mode of formation, and we have examined the particular cases of the isolation of diphenylene oxide $(a)$ from coal tar distillates, and (b) by the distillation of phenol over litharg $\Theta^{2}$.

In the latter case, we isolated diphenylene oxide (styphnate, m.p. $139^{\circ} \mathrm{C}$.), corresponding to the classical formula $\mathrm{C}_{12} \mathrm{H}_{8} \mathrm{O}$, of melting point $82.8-$ $83^{\circ} \mathrm{C}$. (corr.) - not $87^{\circ} \mathrm{C}$. as found by Gallewsky and afterwards by Cullinane. The melting point remained unchanged by further crystallization from alcohol and/or acetic acid, and ultimate analysis gave carbon $85 \cdot 3$ per cent, hydrogen $5 \cdot 0$ per cent.

The isolation of diphenylene oxide from coal tar is closely attended by the lower boiling acenaphthene $\left(\mathrm{C}_{12} \mathrm{H}_{10}\right.$, melting point $95^{\circ} \mathrm{C}$., boiling point $278^{\circ} \mathrm{C}$. $)$ and the higher boiling fluorene $\left(\mathrm{C}_{13} \mathrm{H}_{10}\right.$, melting point $114-115^{\circ} \mathrm{C}$., boiling point $293^{\circ} \mathrm{C}$.). The accompanying graph illustrates equilibrium diagrams, based on pure components, which we have constructed using the thaw-melt method for the systems acenaphthene-diphenylene oxide, diphenylene oxidefluorene.

It will be noted that diphenylene oxide isolated from coal tar and possessing a melting point lower than $82^{\circ} \mathrm{C}$. is probably contaminated with ace. naphthene, a higher melting point indicating probable contamination with fluorene.

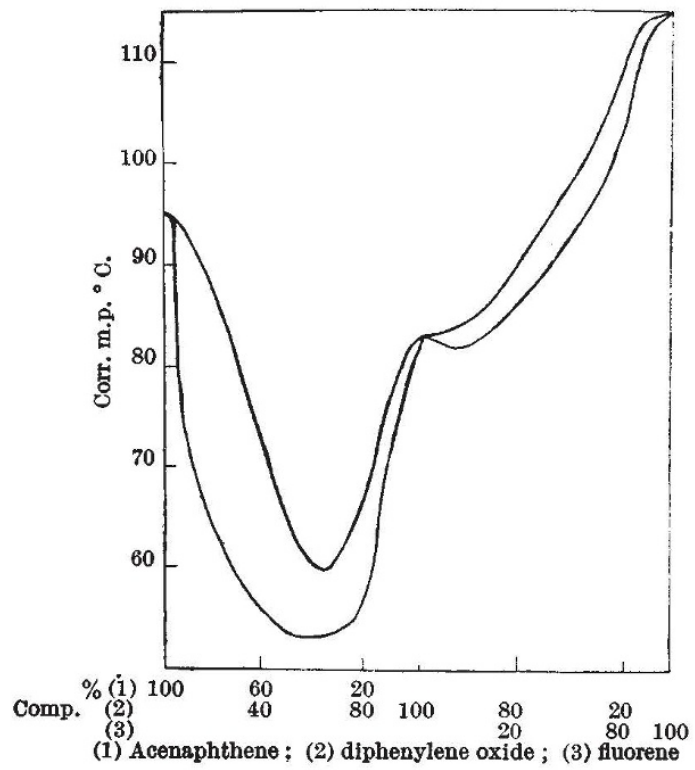

It is where fluorene is the contaminant that caution is needed in describing the purity of diphenylene oxide, for up to 20 per cent contamination changes the melting point but little from $82 \cdot 8^{\circ} \mathrm{C}$. From the graph, coal tar diphenylene oxide with a melting point of $86^{\circ} \mathrm{C}$. would contain about 35 per cent fluorene: this is roughly substantiated by our ultimate analysis of such a sample (carbon, $88 \cdot 0$ per cent; hydrogen, $\mathbf{5 \cdot 2}$ per cent), which can be calculated to correspond with a mixture of 7 parts of diphenylene oxide and 3 parts of fluorene.

\section{A. Fowler WiLLIAMS}

Powell Duffryn Research Laboratories,

140 Battersea Park Road,

London, S.W.11. June 23 .

${ }^{1}$ Hoffmeister, Ann., 159, 211 (m.p. 80-81 ${ }^{\circ}$ C.).

${ }^{2}$ Gallewsky, Ann., 264, 189 (1891) (86-87 C.). (Cullinane, J. Chem. Soc., $2268(1930)\left(86-87^{\circ} \mathrm{C}.\right)$.)

${ }^{3}$ Graebe and Ullmann, Ber., 29, 1876 (1896) $\left(80-81^{\circ} \mathrm{C}\right.$.)

${ }^{4}$ Cullinane, Morgan and Plummer, Rec. Trav. Chim., 56, $6\left(83^{\circ}\right.$ C.).

${ }^{5} \mathrm{Kruber}$, D.R.P., $491,594\left(84^{\circ} \mathrm{C}\right.$.).

6 Hale and Stoesser, U.S.P. $1,808,349\left(82-83^{\circ} \mathrm{C}\right.$ )

" "International Critical Tables", 1, $244\left(87^{\circ} \mathrm{C}\right.$ ).

\section{Structure of Carbon Monofluoride}

Ruff and Bretschneider ${ }^{1}$, in collaboration with Ebert, reported that the X-ray diffraction pattern of carbon monofluoride, (CF $)_{n}$, had similar $(h k .0)$ reflexions to graphite, but that the $(000 l)$ and other reflexions dependent on the $c$ or carbon interlayer spacing were absent. From this they assumed that in carbon monofluoride the graphite structure is retained with expansion perpendicular to the carbon layers and, from a determined density of $2 \cdot 39$, calculated the carbon interlayer spacing to be $8 \cdot 17 \mathrm{~A}$. They postulated that the fluorine atoms acquire electrons from the carbon rings and that the ions so produced lie in a closely packed structure in six parallel layers between each pair of carbon planes requiring a theoretical carbon interplanar spacing of 8.05 A. Although such a structure could reasonably account for the low electrical conductivity and explosive decomposition of the compound, it is very doubtful, as pointed out by Bigelow ${ }^{2}$, whether such an arrangement would have even limited stability. Bigelow proposed an alternative structure in which 